\title{
The role of ecotourism in conservation: panacea or Pandora's box?
}

\author{
OLIVER KRÜGER \\ Department of Zoology, University of Cambridge, Downing Street, Cambridge CB2 3EJ, UK (e-mail: \\ ok212@cam.ac.uk; fax: +44-1223-336676)
}

Received 28 April 2003; accepted in revised form 11 November 2003

Key words: Ecotourism, Flagship species, Local community, Nature-based tourism, Sustainability

Abstract. Does ecotourism contribute towards conservation of threatened species and habitats or is it just a marketing ploy of the tourism industry? Using 251 case studies on ecotourism from the literature, I looked at the distribution of case studies over continents, habitats and flagship species types and what factors influenced whether an ecotourism regime was perceived as ecologically sustainable by authors. Over $50 \%$ of ecotourism case studies were reported from Africa and Central America. The overall distribution of ecotourism case studies did not reflect vertebrate endemism, nor overall tourism distribution in terms of tourist numbers and receipts. There were significant differences between continents and habitats with regard to the proportion of sustainable case studies: ecotourism is perceived to be less sustainable in South America and Asia, and in island and mountain habitats. The type of flagship species also influenced whether ecotourism was classified as sustainable or not: ecotourism with no flagship species was rarely classified as sustainable while charismatic bird and mammal species were associated with a higher probability of sustainability. In a multivariate analysis, flagship species type and local community involvement were important predictors of sustainability in ecotourism. Detailed a priori planning, local involvement and control measures were perceived by authors of case studies to increase the success of ecotourism in conservation. They also perceived that ecotourism can only be an effective conservation tool under certain conditions. If these are met, the evidence indicates that ecotourism can make a contribution to conservation.

\section{Introduction}

The idea of ecotourism, a form of nature-based tourism, contributing both towards socioeconomic and environmental benefits, burst into the scientific and later public consciousness in the 1990s (Wearing and Neil 1999). It can now be considered one of conservation biology's hottest 'buzzwords' (Aylward et al. 1996). The rise of interest in ecotourism can be largely attributed to the rise of the term sustainability, in turn first widely popularised after the famous Brundtland Report was published in 1987 (WCED 1987). The report identified the need for sustainable development and conservation of resources. However, the dilemma of conserving nature while achieving short-term economic gains to satisfy people was faced by many countries, especially those less developed (McNeely et al. 1990; Myers et al. 2000). Ecotourism seemed to be the perfect alternative. It generates much needed foreign currency, both locally and nationally, while at the same time providing a strong incentive to manage nature's strongholds in a way that would conserve them. Consequently, ecotourism is seen almost as a panacea for the protection of nature 
by some authors (e.g., Stiles and Clark 1989; Place 1991; Ruschmann 1992; Burnie 1994; Gurung and De Coursey 1994; Gossling 1999), whereas other authors argue that tourism of any kind is always a threat to protected areas (Wheeller 1992; Cater 1994a,b; King and Stewart 1996; Wall 1997), or that the revenues created by ecotourism are too small to support conservation on a larger scale (Durbin and Ratrimoarisaona 1996), or that ecotourism and conservation can only be antagonistic (Boyle and Sampson 1985; Isaacs 2000). This debate is exacerbated by the fact that the term ecotourism still lacks an agreed definition (Boo 1990; Goodwin 1996; Wearing and Neil 1999), that sustainability is also an ambiguous term which is very difficult to measure objectively (Wearing and Neil 1999), and that sometimes ideology alters the perception of facts (e.g., Vivanco 2001). For example, Loon and Polakow (2001) define an ecotourism operation simply as a hotel situated in natural areas, whereas Ceballos-Lascurain (1987, cited in Boo 1990) has defined it as follows: "Travelling to relatively undisturbed or uncontaminated natural areas with the specific objective of studying, admiring, and enjoying the scenery and its wild plants and animals, as well as any existing cultural manifestations (both past and present) found in these areas". Given this confusion over terminology, it is hardly surprising that the debate often focuses on semantic details rather than the effects of ecotourism on natural resources.

For ecotourism projects to be sustainable, Aylward et al. (1996) suggested four different criteria be met: visitation, finance, ecology, economics. In contrast to nonsustainable forms of landuse, ecotourism should be managed to put ecological sustainability above all other criteria (Aylward et al. 1996). The overall potential of ecotourism to generate revenues for conservation is enormous (Hoyt 1996; Davis and Tisdell 1998; Leader-Williams 2002). It can be estimated that annual growth rates of ecotourism in the 1990s have been twice as high as the overall tourism growth rate of $6 \%$ (Groombridge 1992; Cater 1994a). Growth estimates range from 10 to $30 \%$ (Vickland 1989; Kallen 1990), the large fluctuation being mainly caused by difficulties in definition (Wearing and Neil 1999). In financial terms, Goodwin (1996) predicted a revenue created by ecotourism and environmentally sensitive tourism to be 50 billion and 300 billion US\$ in the year 2000, respectively. Ecotourists in general are well educated with a tertiary education and a high income (Chi and Luzar 1998; Wearing and Neil 1999) which results in a higher willingness to spend money in the destination country (Boo 1991; Wight 1996). Their psychographic characteristics include the possession of an environmental ethic and a willingness not to degrade the resource (Wearing and Neil 1999). This indicates the large potential ecotourism might have in raising not only revenues for conservation but also awareness among people who often support conservation schemes after an ecotourism experience (Wearing and Neill 1999).

While there are numerous articles on the meaning of the terms ecotourism and sustainability, and even textbooks on how to implement an ecotourism project (Beeton 1998), or on ecotourism itself (Fennell 1999; Wearing and Neil 1999), there are hardly any comparative studies which try to assess whether ecotourism has positive or negative effects on the areas or species on which it is founded. It is certainly very difficult to measure objectively or classify a project as being 
successful or sustainable, given the variety of factors involved (Margoluis and Salafsky 1998; Salafsky and Margoluis 1999). Nevertheless, it would definitely add to our understanding of the interrelationships between conservation goals, economic necessities and poverty relief for local people if an attempt was made to identify key factors perceived as influencing the outcome of a conservation project in general and ecotourism in particular (Wall 1997; Perez and Byron 1999; Myers et al. 2000). The aim of this meta-analysis is to address this need and answer three main questions:

(1) How are ecotourism case studies distributed over time, continents, habitats and types of flagship species. Does this distribution match the distribution of species richness and endemism in any way?

(2) What variables are correlated with an ecotourism case study being classified as ecologically sustainable or non-sustainable by the authors? What is the relative importance of these variables in a multi-factor analysis of sustainability?

(3) What are the main positive and negative effects reported in ecotourism case studies? Can these effects be linked to the main reasons perceived by the authors for sustainability or non-sustainability of an ecotourism project?

\section{Methods}

The data set

The data for the meta-analysis was retrieved by searching the Web of Knowledge (http://wok.mimas.ac.uk) database using the key words ecotourism, nature-based tourism and sustainable tourism. This database covers natural as well as social sciences, which was very important since ecotourism literature is found in both fields. I only included case studies if they dealt with tourism focussed on natural areas with the specific objective of studying, admiring, and enjoying the scenery and its wild plants and animals, found in these areas (following the definition of Ceballos-Lascurain 1987). The time span covered ranged from 1981 to September 2001. In addition, there are several books on ecotourism which were searched for case studies (Boo 1990; Cater and Lowman 1994; Ceballos-Lascurain 1996; Liddle 1997; Weaver 1998; Fennell 1999; Reid 1999; Wearing and Neil 1999, Hulme and Murphree 2001). Other studies discussed in papers were also retrieved which helped in finding case studies published before 1981. I am the first to admit that many other case studies will have been omitted, because many case studies get published in project reports, theses and similarly inaccessible forms. However, my approach retrieved as many case studies as possible within a reasonable time. Case studies were divided into two categories: proposal and consequence. A proposal case study was defined as a paper proposing to conserve a certain species or area using ecotourism at a specified locality. A consequence case study was defined as a paper investigating the benefits or impacts that an already running ecotourism project had on a species, area or local community. 
A consequence case study was only included if it met several criteria. First, it had to focus on a particular area, hence overall assessments of ecotourism in terms of sustainability or financial viability were not included. Secondly, it had to report original observational or other data rather than reanalysing already published data. Thirdly, purely theoretical studies looking at ways to quantify ecotourism revenues or sustainability were also omitted. By including only case studies meeting these criteria, it was possible to assign each case study to an area, with a certain type of flagship species and to classify it as sustainable or not depending on the conclusions drawn by the authors. Because I relied on the conclusions drawn by authors, I also included whether an author was a social or natural scientist and whether the author was from outside the case study country or within. There were case studies where it was difficult to classify them as either sustainable or not, given that sustainability is such an ambiguous term (Wearing and Neil 1999). Aylward et al. (1996) use visitation, finance, ecology and economics as four corner stones defining a sustainable ecotourism project. I assessed each case study on the basis of the ecological criterion alone, simply because hardly any case study looked at all four aspects outlined by Aylward et al. (1996). All case studies, however, try to assess whether an ecotourism project is ecologically sustainable. Although ideally one would like to include finance, economics and visitation into the assessment, an ecotourism project which fails to meet ecological sustainability jeopardises its basis, so my admittedly narrow definition of sustainability can be seen as assessing whether an ecotourism project meets the minimum requirement of ecological sustainability. Ecological sustainability was accepted if the current practise does not pose a risk to the area or species in the foreseeable future. This approach to sustainability reflects both the impact of ecotourism itself on the area as well as the effect of ecotourism as a means of alleviating community impacts by providing indirect economic incentives for conservation. This is not necessarily the best definition of sustainability, but it is one that allowed most case studies to be classified with great stringency. For example, if an ecotourism project affected the behaviour of the flagship species with no apparent consequences for reproduction or survival, I classified the case study as sustainable although there was a negative effect of ecotourism on the flagship species. However, there were few cases $(<5 \%)$ which were difficult to assign, using the definition above, so that the results are not qualitatively affected.

\section{Data analysis}

The distribution of case studies between continents, habitats and flagship species types was analysed using contingency tables and non-parametric $\chi^{2}$-tests. This technique was also applied to test for differences in the proportion of sustainable case studies. If any category had a sample size fewer than five, it was omitted from the analysis (Zar 1999). That is why Europe and Antarctica were not included in contingency analyses.

In the multivariate analyses (Table 1) of the 188 consequence case studies, each continent and habitat type was included separately using a dichotomous dummy 
Table 1. Description of variables used in the multivariate analysis of sustainability as the dependent variable.

\begin{tabular}{|c|c|}
\hline Variable & Description \\
\hline (1) Year & Year in which the case study was published \\
\hline (2) Author type & $\begin{array}{l}\text { Dichotomous variable describing whether the authors } \\
\text { were affiliated to an institution of the case study country or not }\end{array}$ \\
\hline (3) Author background & $\begin{array}{l}\text { Dichotomous variable describing whether the case study } \\
\text { was reported by a natural scientist or a social scientist }\end{array}$ \\
\hline (4) Continent or region & $\begin{array}{l}\text { Continent or region in which the study was conducted } \\
\text { (Europe, Africa, Asia, Oceania, Antarctica, South America, } \\
\text { Central America, North America). Dichotomous dummy } \\
\text { variables were used to consider each continent separately }\end{array}$ \\
\hline (5) Habitat type & $\begin{array}{l}\text { Habitat in which the study was conducted (coral reef, } \\
\text { coastline, freshwater, island, mountain, savannah, temperate } \\
\text { forest, tropical forest). Dichotomous dummy variables were used }\end{array}$ \\
\hline (6) Flagship species & $\begin{array}{l}\text { Type of flagship species of the case study }(0=\text { none, } 1=\text { fish, } \\
2=\text { reptile, } 3=\text { bird, } 4=\text { charismatic bird, } 5=\text { mammal, } \\
6=\text { charismatic mammal, } 7=\text { world-wide flagship })\end{array}$ \\
\hline (7) Local community involved & $\begin{array}{l}\text { Dichotomous variable describing whether there was local } \\
\text { community involvement or not }\end{array}$ \\
\hline (8) Investigation method & $\begin{array}{l}\text { Dichotomous variable describing whether the study was } \\
\text { purely observational }=0 \text { or whether a repeatable method } \\
\text { was used }=1 \text { (questionnaires, willingness to pay, } \\
\text { ravel-cost method, etc.) }\end{array}$ \\
\hline
\end{tabular}

variable (e.g., if a case study came from Africa $=1$, otherwise $=0$ ). This allowed for testing whether any continent or habitat was sufficiently more likely to produce sustainable case studies to enter as a significant predictor of the dichotomous dependent variable sustainability $(0=$ unsustainable and $1=$ sustainable). Local community involvement was also entered as a dichotomous variable $(0=$ no involvement, $1=$ involvement). I defined local involvement as either a scheme of revenue sharing with local communities, decision power about the project being given to local communities or a substantial amount of the labour force drawn from local communities. Again there were borderline cases where the classification was difficult, but these few cases would not qualitatively alter the results reported here. I am also the first to admit that revenue sharing, decision power and labour recruitment are not equally important measures of local community involvement, but the dichotomous variable reflects merely any local participation reported by authors as opposed to none. The type of flagship species was scored in an ascending order in seven categories and entered as a factor (see Table 1). I made three exceptions from the general taxonomic approach, adding the categories charismatic bird, charismatic mammal and world-wide flagship species. These were included to reflect that certain bird and animal species are especially appealing to humans. The category charismatic bird included penguins, albatrosses, birds of prey and parrots, the category charismatic mammal included all non-ape primates, bears, wolves, kangaroos and koala bears. The category world-wide flagship finally included all apes, the large felid predators, elephants, rhinos and whales. 
The relative importance of these variables in determining whether an ecotourism project was classified as sustainable or not was analysed using a multivariate logistic regression analysis in SPSS. To check model robustness, a multiple discriminant analysis was also carried out.

\section{Results}

Distribution of ecotourism case studies over time, space and species

Although the term ecotourism was coined only in 1972 (Myers 1972), the first case study meeting the criteria specified in the methods section appeared in 1969. Overall, 251 case studies satisfied the criteria and were included in the analysis. Out of these 251, 63 case studies or $25.1 \%$ were classified as being a proposal and 188 (74.9\%) as being a consequence study. As can be seen from Figure 1, the number of case studies remained quite low until the end of the 1980s. From 1989 onwards, the number of case studies increased rapidly and reached an overall high in 1992, partly due to the IV World Congress on National Parks and Protected Areas and the number of case studies subsequently published in Ceballos-Lascurain (1996). Subsequently, the 1990s saw, on average, around 20 case studies being published each year. Overall, there is a highly significant correlation between time and the number of case studies published $(r=0.779, \mathrm{df}=31, P<0.001)$. The higher number of case studies in the 1990s was not a consequence of an increase in proposal studies which showed no trend over time $(r=0.269, \mathrm{df}=10, \mathrm{~ns})$. A time trend found was an increase in the number of consequence studies reporting a sustainable ecotourism project $(r=0.692, \mathrm{df}=10, P<0.02)$.

The distribution of case studies over countries, continents and habitats is skewed. Case studies came from 57 different countries covering all continents. The distribution between continents or regions shows that Africa has the biggest share of case studies (Figure 2a, 27\%), followed by Central America (25\%) and Asia (16\%). The high proportion for Central America is mainly a consequence of Costa Rica being the prime country for ecotourism studies (Table 2). With regard to the distribution of case studies between major habitat types (Figure 2b), tropical forest had the biggest share (35\%), followed by savannah (19\%) and coastline (15\%).

In order to see whether the distribution of ecotourism case studies in any way resembles the distribution of surface area or endemism, I first compared the 10 countries with the highest number of case studies with their overall tourism and revenue level (Table 2). They comprise around $15 \%$ of the total number of international tourist arrivals in 2000 and tourism in general created only between 0.5 and $13.5 \%$ of the GDP of these countries. Hence, with the exception of Belize, ecotourism has a negligible impact on the GDP of these countries. As can be seen from Table 2, only three countries (Australia, Mexico, USA) are among the top 10 countries in both ecotourism case studies and endemic vertebrate species richness and the top 10 countries in terms of international tourist arrivals and tourism receipts do not, with the exception of the USA and Canada, include prominent ecotourism destinations. 


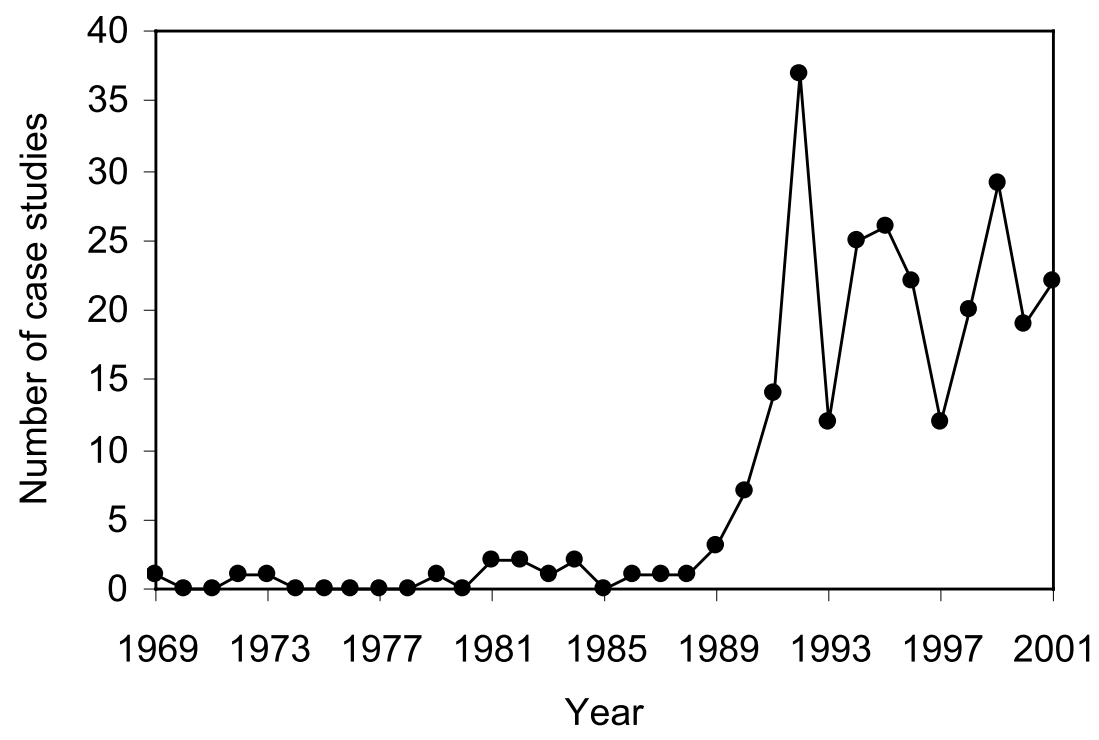

Figure 1. Time series of the number of ecotourism case studies over time.

To elaborate this further, I compared the proportion of case studies between continents and regions with the proportion of the continents' surface area, the proportion of area protected (IUCN categories I-V) and the number of endemic vertebrate species, corrected for the species-area relationship (Figure 3). There is a highly significant difference between the proportion of case studies and the proportion of surface are $\left(\chi^{2}=794.9, \mathrm{df}=7, P<0.0001\right)$. Especially underrepresented in terms of ecotourism studies for their area are Europe, Asia and Antarctica, while Oceania and Central America are overrepresented for their area. With the exception of Antarctica, in all continents or regions between 5 and $11 \%$ of the surface area is protected (Groombridge 1992; McNeely 1994). The differences in the number of endemic vertebrate species (corrected for the species-area relationship) between continents and regions are not reflected in the proportion of ecotourism case studies: there is a highly significant difference $\left(\chi^{2}=118.8, \mathrm{df}=7, P<0.0001\right)$. Underrepresented in terms of ecotourism studies compared to the degree of vertebrate endemism are Oceania, South America and Asia, while Africa, Central and North America are overrepresented for their level of vertebrate endemism. The high number of researchers in North America might largely be responsible for the high number of studies compared to vertebrate endemism in North and Central America. The comparison between studies and vertebrate endemism means that although Oceania is the focus of more ecotourism studies than expected from its size, it is not receiving enough focus in terms of ecotourism studies given their vertebrate endemism level, while Asia is understudied from both an area and endemism point of view.

Focussing on the type of flagship species and the distribution of ecotourism studies shows that $27 \%$ of studies focussed on world-wide flagship species, followed 

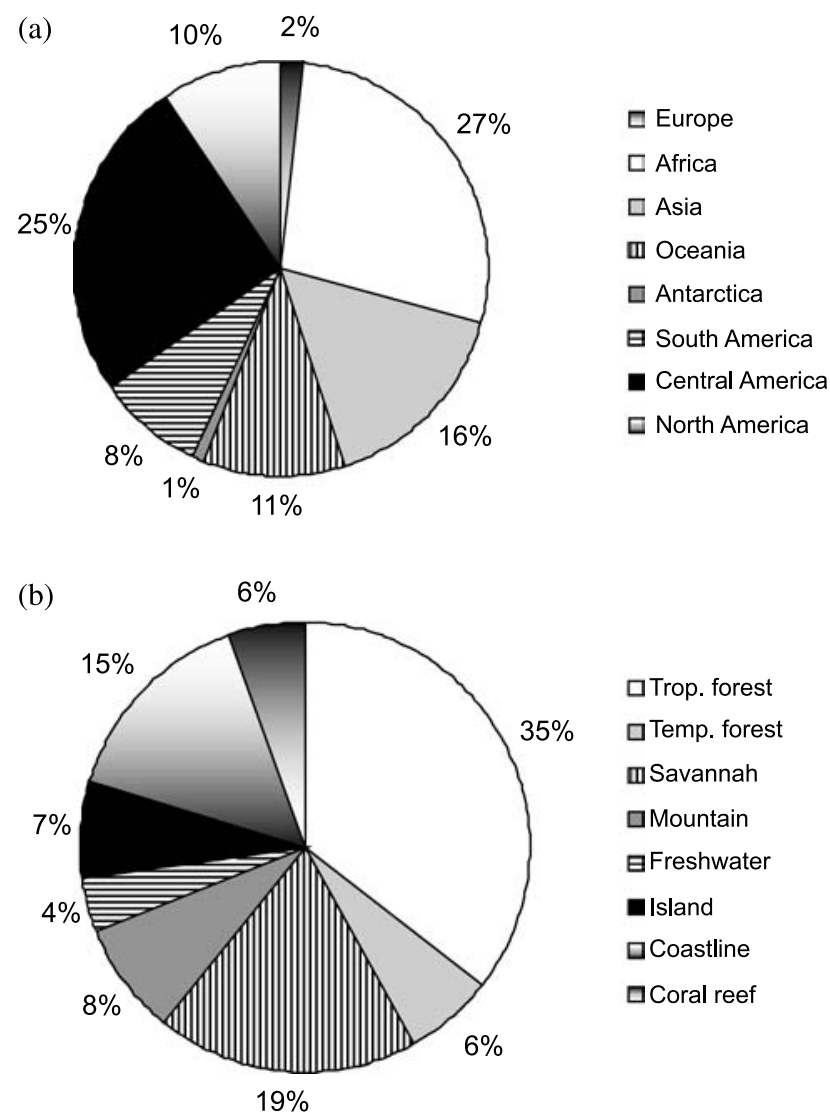

Figure 2. Distribution of ecotourism case studies over continents and regions (a) and between major habitat types (b).

by birds $(26 \%)$ and $12 \%$ which had no flagship species at all (Figure 4). The proportion of proposal studies differed significantly between flagship species types $\left(\chi^{2}=19.796, \mathrm{df}=7, P=0.002\right)$. The proportion of proposals was underrepresented in the categories no flagship and birds while it was overrepresented in the categories fish, charismatic bird, and charismatic mammal. The high proportion of studies involving a flagship species is partly a direct consequence of the many studies from Africa, where many of the flagship species are found.

\section{Determinants of sustainability in ecotourism projects}

Out of the 188 case studies classified as being a consequence study, 118 or $62.8 \%$ were classified as being a sustainable ecotourism project. This a significantly higher proportion than expected by chance alone $\left(\chi^{2}=12.255, \mathrm{df}=1, P=0.0002\right)$. The 


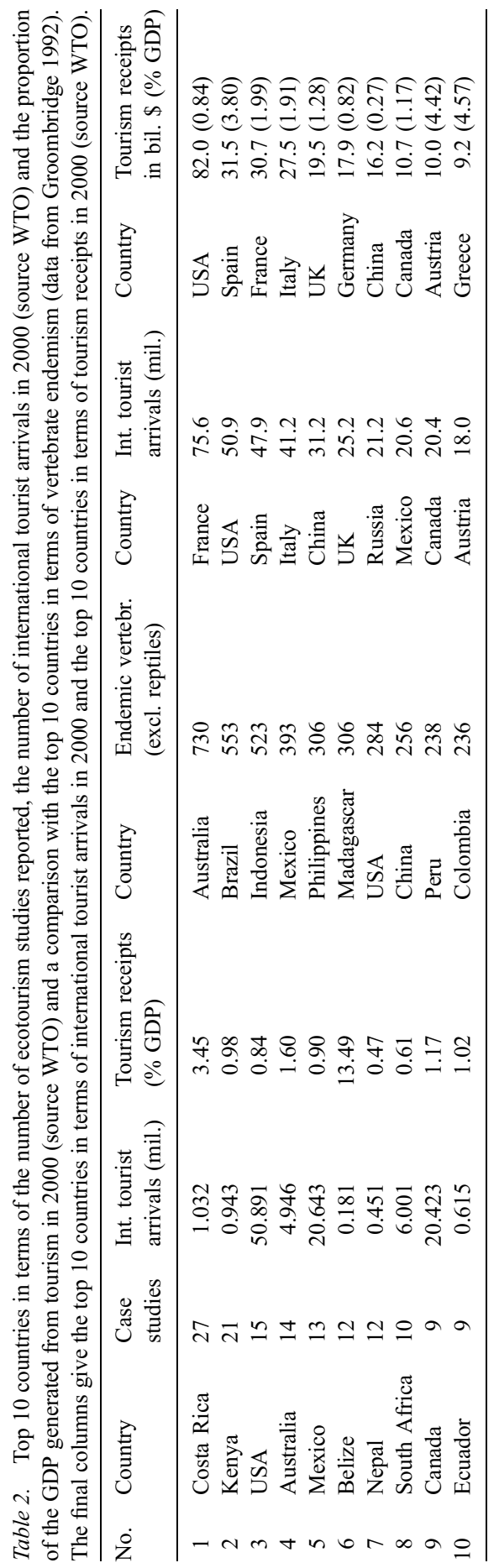




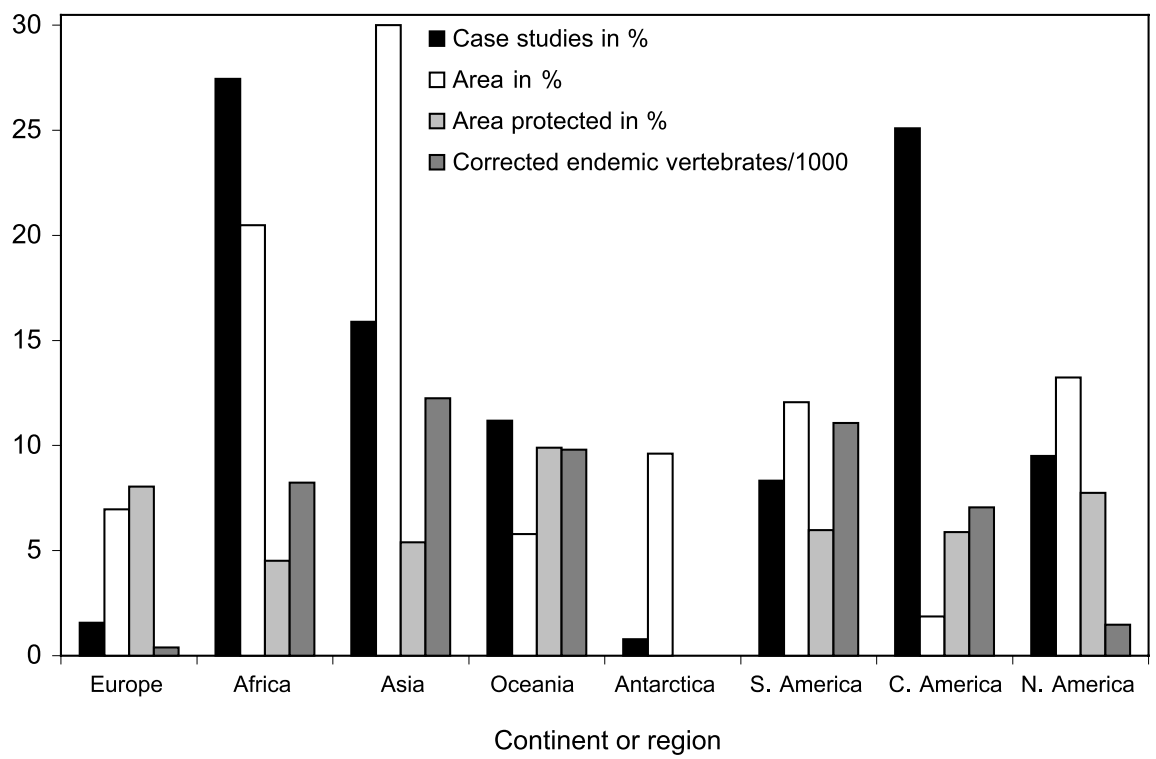

Figure 3. Comparison of the proportion of case studies by continent/region with the proportion of the Earth's land area, proportion of continent/region designated as a protected area, and the number of endemic vertebrate species (corrected for species-area relationship with a $z$-exponent calculated as 0.2 and subsequently divided by 1000) over continents/regions. Data for endemic vertebrate species richness was taken from Groombridge (1992). Note that the figure displays results of several contingency analyses.

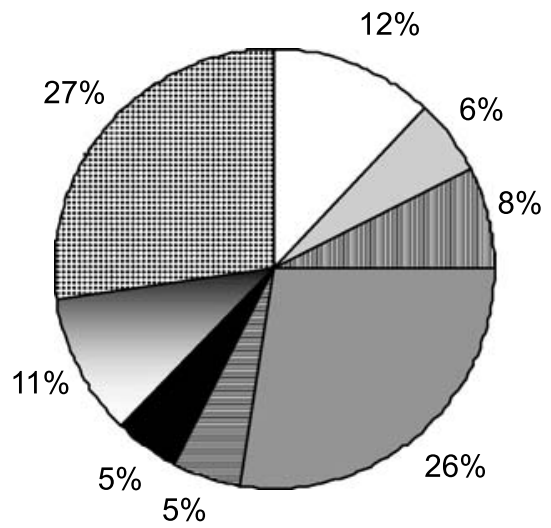

\section{$\square$ None \\ $\square$ Fish \\ ㄸ Reptile \\ $\square$ Bird \\ 目 Charismatic bird}

- Mammal

$\square$ Charismatic mammal

田 World-wide flagship

Figure 4. Distribution of ecotourism case studies between flagship species types.

proportion of sustainable case studies differs significantly between continents and regions (Figure 5a, $\chi^{2}=14.865, \mathrm{df}=5, P=0.005$, excluding Europe and Antarctica because of small sample size). While North America had a much higher 
(a)

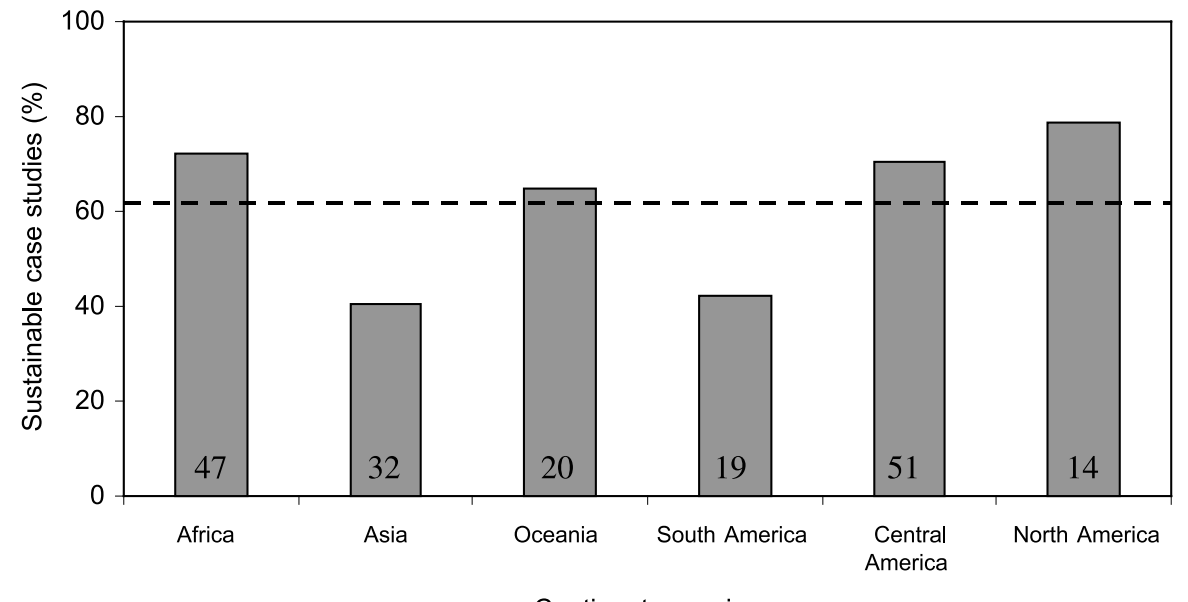

(b)

Continent or region

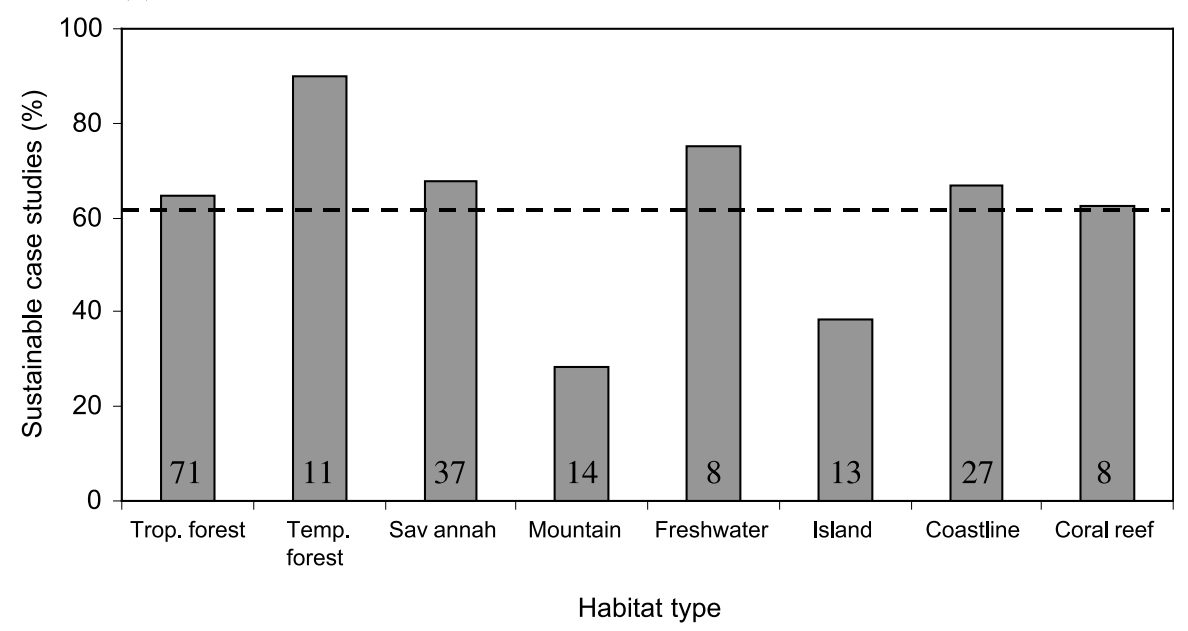

Figure 5. Proportion of ecotourism consequence studies classified as sustainable over continents and regions (a) and between major habitat types (b) with dashed lines showing the overall proportion of sustainable case studies. Numbers at the bottom of the bar give the number of case studies available.

proportion of case studies classified as sustainable (78.6\%) than the overall average, the proportion was particularly low in Asia (40.6\%) and South America (42.1\%). The proportion of case studies classified as sustainable also differed significantly between habitat types (Figure $5 \mathrm{~b}, \chi^{2}=14.776, \mathrm{df}=7, P=0.013$ ). Ecotourism was classified as sustainable especially in temperate forest environments $(90 \%$ sustainable) but not in island (38.5\% sustainable) or mountain environments $(28.6 \%$ sustainable). 


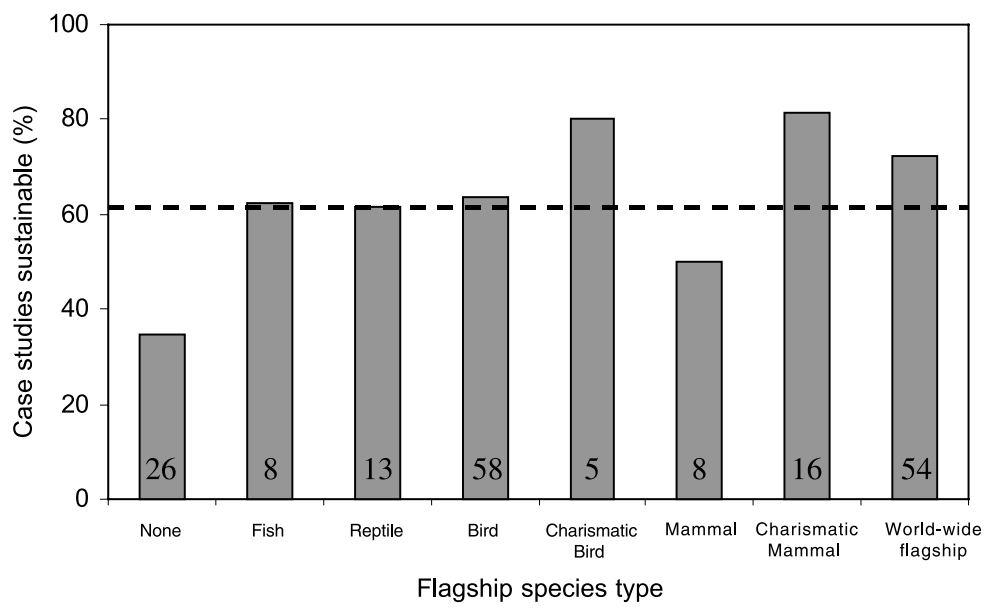

Figure 6. Proportion of ecotourism consequence studies classified as sustainable between flagship species with the overall proportion shown as the dashed line. Numbers at the bottom of the bar give the number of case studies available.

With regard to flagship species type, there were also profound differences in the proportion of case studies classified as sustainable (Figure 6, $\chi^{2}=14.661, \mathrm{df}=7$, $P=0.014)$. Ecotourism projects with no flagship species $(34.6 \%)$ or a mammal flagship species $(50 \%)$ had an especially low proportion of sustainable case studies while the proportion of sustainable case studies was especially high in projects with a charismatic bird $(80 \%)$, charismatic mammal $(81.3 \%)$ or a world-wide flagship species $(72.2 \%)$.

In order to see which of these factors were most important in determining whether a case study was classified as sustainable or not, I performed a multivariate logistic regression analysis using sustainability as the dichotomous dependent variable. The best model (Table 3 ) included four predictor variables and was highly significant, with an $R^{2}$ of 0.65 and it classified $87.8 \%$ of case studies correctly as either sustainable or unsustainable. One habitat type (temperate forest) entered the model with its dummy variable, indicating that its proportion of sustainable case studies was significantly above average. The type of flagship species was also a significant predictor, so was the dichotomous variable local community involvement. Finally, the investigation method entered as a significant predictor: purely observational studies were more likely to report unsustainability whereas studies employing repeatable techniques such as questionnaires, travel-cost method or willingness to pay were more likely to report sustainability, maybe indicating a higher level of management and monitoring. To check for model robustness, a multiple discriminant analysis was also performed and the same variables were chosen as significant predictors and this model classified $85 \%$ of cases correctly as sustainable or not, indicating that the results are not sensitive to the statistical method used. 
Table 3. Results of the multivariate logistic regression analysis using sustainability as the dependent variable. The model classifies $87.8 \%$ of case studies correctly as either sustainable or unsustainable with a pseudo $R^{2}$ of 0.65 . The variable flagship species type does not have a single slope $\beta$, because it is a factor.

\begin{tabular}{lrrrrrr}
\hline Variable & Log-likelihood & df & $P$ & $\beta$ & s.e. & $P$ \\
\hline Constant & 30.134 & & & -28.876 & 1.819 & 0.001 \\
Temperate forest & 41.766 & 1 & 0.001 & 4.074 & 1.509 & 0.007 \\
Flagship species type & 51.020 & 7 & 0.004 & Positive & & \\
Local community involved & 152.485 & 1 & 0.001 & 22.989 & 1.004 & 0.001 \\
Investigation method & 41.522 & 1 & 0.001 & 2.335 & 0.761 & 0.002 \\
\hline
\end{tabular}

Table 4. Results of the multivariate logistic regression analysis using positive contribution to conservation as the dependent variable. The model had a pseudo $R^{2}$ of 0.24 , was highly significant $\left(\chi^{2}=37.580, \mathrm{df}=7, p<0.001\right)$ and classified $84.6 \%$ of case studies correctly.

\begin{tabular}{lllllll}
\hline Variable & Log-likelihood & df & $P$ & $\beta$ & s.e. & $P$ \\
\hline Constant & 47.304 & & & 5.868 & 1.702 & 0.001 \\
Author background & 55.762 & 1 & 0.004 & 1.640 & 0.644 & 0.011 \\
Africa & 58.940 & 1 & 0.001 & -2.526 & 0.865 & 0.004 \\
Asia & 56.504 & 1 & 0.002 & -1.989 & 0.731 & 0.006 \\
Central America & 54.030 & 1 & 0.010 & -1.541 & 0.624 & 0.014 \\
Coastline & 53.124 & 1 & 0.016 & -2.114 & 1.061 & 0.046 \\
Savannah & 53.213 & 1 & 0.015 & 1.815 & 0.821 & 0.027 \\
Local community involved & 55.941 & 1 & 0.003 & 1.339 & 0.476 & 0.005 \\
\hline
\end{tabular}

Finally I asked which factors promote case studies not only being classified as sustainable, but making a positive contribution to conservation. So I re-classified all case studies as either making a positive contribution (1) or being neutral or negative to conservation (0). A positive contribution was defined as stabilising or increasing a threatened species' population or that new areas were being protected. Only 33 out of 188 case studies $(17.6 \%)$ made a positive contribution, which is much lower than expected by chance $\left(\chi^{2}=79.171, \mathrm{df}=1, P<0.0001\right)$. The best multivariate logistic regression model is given in Table 4 and explained only $24 \%$ of the variation with seven predictor variables. As in the model for sustainability, local community involvement made a positive contribution to conservation more likely. Case studies with a positive contribution were more frequently reported from social scientists than from natural scientists. Three continents and one habitat type (Africa, Asia, Central America and coastline) decreased the probability of a case study being classified as making a positive contribution to conservation whereas savannah increased this probability. Interestingly, flagship species type did not enter the model and the explanatory power was much less compared to the model for sustainability. 
Table 5. Main negative and positive effects of ecotourism projects and perceived reasons for success or failure.

\begin{tabular}{|c|c|}
\hline Unsustainable case studies $(\mathrm{n}=70)$ & Case studies in $\%$ \\
\hline \multicolumn{2}{|l|}{ Types of unsustainability } \\
\hline Habitat alteration, soil erosion, pollution & 45.6 \\
\hline Local community not involved, leads to consumptive land-use & 25.0 \\
\hline Flagspecies affected, population decline, serious behaviour alteration & 20.6 \\
\hline Not enough revenue creation for conservation, consumptive use practised & 8.8 \\
\hline \multicolumn{2}{|l|}{ Reasons for unsustainability } \\
\hline Too many tourists & 36.8 \\
\hline Local community not involved & 27.9 \\
\hline Not enough control and management & 14.7 \\
\hline Not enough local revenue creation & 10.3 \\
\hline Protected area has priority over local people & 7.4 \\
\hline Locals do not get environmental education & 2.9 \\
\hline \multicolumn{2}{|l|}{ Sustainable case studies $(n=118)$} \\
\hline \multicolumn{2}{|l|}{ Effects of sustainable case studies } \\
\hline More conservation (new areas, more effective) & 44.1 \\
\hline Revenue creation increased for local communities, non-consumptive use & 28.8 \\
\hline Increased revenue creation, regionally and nationally & 21.2 \\
\hline Conservation attitude of local communities changed & 5.9 \\
\hline \multicolumn{2}{|l|}{ Reasons for positive effects } \\
\hline Local community involved at most stages & 38.5 \\
\hline Effective planning and management & 33.3 \\
\hline Ecotourism simply an economic advantage, locally and regionally & 17.1 \\
\hline Flagship species alone & 6.0 \\
\hline Differential pricing of entry fees & 5.1 \\
\hline
\end{tabular}

Consequences of ecotourism projects and perceived reasons for success or failure

The 70 case studies which were classified as unsustainable could be divided into four major types of unsustainability (Table 5). Almost half of all unsustainable case studies reported that ecotourism led to serious habitat alteration, mainly in the form of major habitat changes in order to accommodate more ecotourists, serious trail erosion due to a high number of people or cars on a certain track and pollution caused by ecotourists in mostly fragile areas, such as islands or mountain regions. Examples of that type include large-scale habitat transformation to enhance ecotourism experience in Malaysia, track erosion in Costa Rican National Parks and severe pollution by garbage at certain points in the Himalayas in Nepal. Another type of unsustainability identified was the exclusion of the local community from economic benefits of the protected area on which ecotourism was based. This happened in a quarter of all unsustainable case studies. The exclusion of local communities from the economic benefits derived from ecotourism led either to increased poaching, timber felling or other forms of consumptive landuse. The third 
major type of unsustainability was the direct effect on the flagship species, ranging from population decline to serious behaviour alteration with potential consequences for the population. Finally, a fourth but less important type of unsustainability was simply that ecotourism did not create enough revenues to prevent consumptive landuse. This type of unsustainability was generally found in areas where either access is difficult or attractive flagship species were missing. Very much linked to these types of unsustainability were the different reasons identified for unsustainability (Table 5). The most important reasons for an unsustainable ecotourism project were that the number of tourists was simply too high which was reported from over a third of all unsustainable case studies. In a way, successful ecotourism projects subsequently fall victim to their own success if tourist numbers are not strictly controlled or quotas are not enforced. The second most important reason for failure was the failure to involve local communities. Linked to the problem of visitor numbers is the notion that there was not enough control and management so that unsustainable practices can spread. The three minor reasons for failure of ecotourism projects are again linked to local community involvement. Either an ecotourism project did not create enough revenues locally to prevent consumptive landuse, or that conservation had priority over people so that the local attitude towards conservation became hostile, resulting in poaching, or that there was no component of local education and hence local attitudes towards conservation did not change, mainly because local communities did not appreciate the non-consumptive value of the protected area on which ecotourism was based.

The benefits of sustainable ecotourism could be grouped into four categories. The predominant effect was that through ecotourism either new areas received protection or existing protected areas were conserved more effectively because of a higher incentive to do so. Another important effect of sustainable ecotourism projects was an increase in revenue creation for local communities, which subsequently led to changes in land-use pattern from consumptive use to non-consumptive use. Different from this local effect was that, in one fifth of all sustainable cases, there was substantial revenue creation on a regional or national scale, leading to shifting priorities in various levels of administration. A final positive effect of ecotourism leading to sustainability was a change in the attitude of local communities towards the protected area in their vicinity which in turn reduced poaching, timber felling and other consumptive landuses. In many cases local communities became actively involved in planning, implementing or executing conservation programmes. The reasons for case studies being sustainable could be grouped into five categories (Table 5). In almost $40 \%$ of cases the consequent involvement of local communities during planning, decision making or as a substantial labour source made ecotourism projects sustainable through reduced need to practise consumptive landuse. Nearly as important as a reason for success of an ecotourism project was thorough planning and management. Many unsustainable projects had not carried out an assessment of their attractiveness to ecotourists and neither did they monitor visitor numbers and impact. To have a strategic plan on how to attract ecotourists (defining what the attraction might be), how many should be attracted, and how the resulting resources should be distributed proved to be very 
important reasons for positive effects occurring over a long time-scale. A third reason for a successful ecotourism project was the amount of revenue created through ecotourism. If ecotourism is far more economically advantageous than other forms of landuse, this economic advantage alone is sufficient to trigger conservation incentives. One minor reason for a successful ecotourism project was the flagship species. Because some flagship species are so appealing, the corresponding projects are successful even when other factors would predict failure. An example of this type is gorilla tourism in Rwanda which currently operates with sufficient tourist numbers despite the great political instability in the region, otherwise an important 'killer' of an ecotourism destination (Wells 1992). So important are gorillas for Rwandan tourism that they have been estimated to account for $75 \%$ of all tourism income (Shackley 1995). Here, the sole driving force is the gorilla and the desire to see it (however, for a more recent negative assessment of gorilla tourism, see Butynski and Kalina 1998). Finally, another minor reason for a successful ecotourism project clearly distinct from the others is differential entry fees. To charge more entry fee from ecotourists from developed countries than from less developed countries can increase revenue creation substantially and make ecotourism the best landuse option.

\section{Discussion}

The rise of interest into ecotourism as a conservation tool over the last 30 years is likely to be even stronger than the time trend I reported here. Many case studies never get published in scientific journals but in progress reports or other grey literature. This is a potential bias influencing the results presented here. Another bias which is hard to quantify is that studies documenting negative results might not get published as readily as positive ones due to referee or editor biases. This might influence the correlation between the proportion of sustainable studies and time and also the strong differences between regions and habitats. I would nevertheless tentatively argue that, over the last 10 years, the success rate might have improved through better planning and understanding of interrelationships between socioeconomic and environmental factors.

The distribution of ecotourism studies across continents and regions highlights two important points. First, the large proportion of studies from Africa reflect the need of ecotourism to rely on easily seen wildlife species (Myers 1972; Munn 1992; Brown and Henry 1993; Moran 1994). It is therefore no surprise that ecotourism really started on the African plains (Myers 1972; Budowski 1976). The reason why Central America is a prime ecotourism area is its proximity to North America. Costa Rica is the prime country of ecotourism studies, thanks to its variety of spectacular landscapes and wildlife and political stability, themselves important components of ecotourism success. Overall, Wells (1992) summarised the five main limits of ecotourism as: lack of infrastructure, difficulties in access, political instability, ineffective marketing and absence of spectacular or readily visible natural features. He concluded that only a minority of protected areas in 
developing countries has the potential for large revenues through ecotourism. If an attractive flagship species is not present, the market for ecotourism is severely limited (Munn 1992), although the ecosystem might be very important in terms of its conservation priority. This bias towards easy-to-see wildlife or proximity to developed countries can be seen in the distribution across habitat types as well, since savannah habitats have a high share of ecotourism studies, only surpassed by tropical forests (again mainly due to the popularity of Central America). This distribution across continents and habitats does not reflect the distribution of biodiversity and endemism (Groombridge 1992; Myers et al. 2000). For example, of the 25 hotspots of biodiversity identified by Myers et al. (2000), at most six are partially covered by countries making the top 10 in ecotourism case studies (Table 2). This indicates that there are many areas with a high conservation priority where it is unlikely that ecotourism could make a substantial contribution towards conservation. One major component attracting ecotourists is a flagship species (LeaderWilliams 2002) and the distribution of proposals and consequence studies across flagship species types highlights this. The proportion of proposal studies was more than average for fish (often proximate for coral reef projects) and charismatic bird and mammal species. Hence the large potential of certain animal species as attractions is realised. Nevertheless one has to be realistic about the potential of a certain flagship species. For example, Salewski et al. (2000) proposed to use ecotourism to protect an endangered species of rockfowl in West Africa. Although rare bird species are appealing to birders, it is unlikely that this is an attractive enough flagship species to make such an ecotourism project successful.

With regard to sustainability of ecotourism, Budowski (1976) already suggested three scenarios for the relationship between ecotourism and conservation: conflict, coexistence or symbiosis. Examples for all three scenarios were found in abundance among the case studies. Overall, $63 \%$ of case studies could be referred to as sustainable, but no great weight should be attached to this overall percentage for three reasons. First, there might be a publication bias towards positive results and although I consider this to be unlikely to be the main reason, it could lead to an overestimate of the sustainability of ecotourism. Secondly, there might be a double bias when writing about sustainability, first from the authors of the case studies and then from myself. Thirdly and more important, the percentage of sustainable case studies depends on the criteria used to define sustainability and since there is no objective way to define it (Wearing and Neil 1999), other authors might come to a quite different percentage of sustainable case studies. I focussed especially on ecological sustainability, but several authors have pointed out that ecotourism should be financially viable and culturally appropriate as well (Aylward et al. 1996; Wall 1997).

Much more important than the overall percentage of sustainability reported here is the fact that certain continents and habitats have a significantly lower percentage of sustainable ecotourism studies. With regard to continents, South America and Asia show a very low percentage of sustainable case studies. There are many potential explanations for this, including again a bias in publishing, the lack of easy-to-see wildlife in many protected areas, difficulties in access severely limiting 
tourist visitation, and high levels of revenue leakages from the regional to the national and international scale (Groombridge 1992; Goodwin 1996). As an example of the latter type, a three day trip to the Komodo National Park in Indonesia with its famous Komodo dragons costs around 300 US $\$$ booked in Jakarta but the admission fee to the park itself is only 1 US $\$$, hence the small revenues do not match the management costs of the park (Wells 1993; but see Walpole et al. 2001).

With regard to habitats, ecotourism does seem to be less sustainable in mountain regions and on islands. The main reason for this might be the higher fragility of these ecosystems and hence a lower carrying capacity for tourists. Environmental damage due to the effects of pollution, overcrowding leading to trail erosion or wildlife disturbance are more often reported from these habitats. The difference between sustainability and unsustainability can be very small in these ecosystems. For example, in the Nepalese Himalayas, ecotourism has been found to be very effective in places (Annapurna, Gurung and De Coursey 1994) and quite detrimental in others (Everest, Coburn 1984; Gurung and De Coursey 1994). Similarly, the Galapagos Islands are a prime ecotourism destination where case studies overwhelmingly come to the conclusion of unsustainability (De Groot 1983; Kenchington 1989; Steele 1995; Nolan and Nolan 1998), despite or even because of the attractive flagship species.

A third factor influencing the probability of sustainability is the type of flagship species the ecotourist might see. The proportion of sustainable examples was quite low for projects which lacked a real flagship species as well as projects based on 'ordinary' (in contrast to charismatic) mammalian species. The reason for the latter being seldom sustainable might be related to the fact that many mammals are shy and difficult to see, the opposite of what ecotourism ideally needs as a flagship species. As ecotourism relies on a steady number of tourists generating revenues, projects without a marketable attraction are likely to be unsuccessful (Boo 1990; Munn 1992; Wells 1992). In such instances, pumping money to establish ecotourism might not be a good option from a conservation point of view (Isaacs 2000). In contrast, three flagship species categories (charismatic bird, charismatic mammal, world-wide flagship) had a higher than average probability of being sustainable. This relationship between attractive animals and ecotourism potential has led Wells (1992) to conclude that only a minority of protected areas in developing countries has the potential to create large revenues through ecotourism.

Combining all these factors in a multivariate analysis of sustainability clearly singled out two important factors: the type of flagship species as discussed earlier and local community involvement. It is, however, worth noting that the type of methodology used in the case study was also a significant predictor. As repeatable methods such as willingness to pay or travel-cost rely more on socioeconomic parameters to assess the success or failure of an ecotourism project, it was sometimes difficult to assess the ecological sustainability on the basis of the information provided in these case studies. With regard to local community involvement, the results are definitely very strong and indicate that local community participation is paramount for the success of an ecotourism project (see also Wells 1993; Heywood 1995; Child 1996). This does not necessarily mean that all decision on planning 
power must be in local hands, because ecotourism often demands either a high level of initial investment (Loon and Polakow 2001) or management knowledge (Salafsky et al. 2001). But ecotourism should not alienate locals from the protected area which still happens (Shackley 1996), and it should provide more than a simple economic advantage over unsustainable forms of land-use. Asking the question how frequently ecotourism makes a positive contribution to conservation (rather than being sustainable) reveals that only $17 \%$ of case studies report a positive effect of ecotourism. A factor promoting this was again local community involvement, but the overall predictive power of the model was much weaker compared to the model for sustainability (Table 3 versus Table 4). To identify factors shifting an ecotourism project from being ecologically neutral to being positive seems to be much harder.

The results emphasise the need for effective control and management of tourist numbers and distribution which came out as one of the most important reasons for unsustainable case studies. Too high tourist numbers and lack of control or management were identified by authors as the main reasons for unsustainability in over $50 \%$ of all studies (Table 4, see also Wilson and Tisdell 2001). Ecotourism can benefit protected areas and the surrounding local communities if it is small-scale and locally operated or owned (Weaver 1991). This has the additional advantage of minimising leakages (Leader-Williams 2002), resulting from import of goods (Boo (1990) and Wells (1993) estimate that between 55 and 66\% of revenues might be lost), while maximising multiplier effects (Cater 1994b). To make ecotourism work for conservation, very careful planning and management is needed before and during development, and parallel to the running of any ecotourism project.

\section{Acknowledgements}

I am indebted to W. Schröder for help in retrieving case studies and to A. Balmford, M. Brooke, S. Butchart, M. Walpole and two anonymous reviewers for comments on the manuscript. This study was funded by a Marie Curie Fellowship and a Churchill College Junior Research Fellowship.

\section{References}

Aylward B., Allen K., Echeverria J. and Tosi J. 1996. Sustainable ecotourism in Costa Rica: the Monteverde Cloud Forest Preserve. Biodiversity and Conservation 5: 315-343.

Beeton S. 1998. Ecotourism: A Practical Guide for Rural Communities. Landlinks, Collingwood, Australia.

Boo E. 1990. Ecotourism: The Potentials and Pitfalls. Vol. 1 \& 2. WWF, Washington, DC.

Boo E. 1991. Planning for ecotourism. Parks 2: 4-8.

Boyle S.A. and Sampson F.B. 1985. Effects of non-consumptive recreation on wildlife: a review. Wildlife Society Bulletin 13: 110-116.

Brown G.M. and Henry W. 1993. The economic value of elephants. In: Edwards G. (ed) Economics and Ecology: New Frontiers and Sustainable Development. Chapman \& Hall, London.

Budowski G. 1976. Tourism and conservation: conflict, coexistence or symbiosis? Environmental Conservation 3: 27-31. 
Burnie D. 1994. Ecotourists to paradise. New Scientist 1942: 23-27.

Butynski T.M. and Kalina J. 1998. Gorilla tourism: a critical look. In: Milner-Gulland E.J. and Mace R. (eds) Conservation of Biological Resources. Blackwell, London, pp. 294-313.

Cater E. 1994a. Introduction. In: Cater E. and Lowman G. (eds) Ecotourism: A Sustainable Option? John Wiley \& Sons, Chichester, UK, pp. 3-17.

Cater E. 1994b. Ecotourism in the third world - problems and prospects for sustainability. In: Cater E. and Lowman G. (eds) Ecotourism: A Sustainable Option? John Wiley \& Sons, Chichester, UK, pp. 69-86.

Cater E. and Lowman G. 1994. Ecotourism: A Sustainable Option? John Wiley \& Sons, Chichester, UK.

Ceballos-Lascurain H. 1996. Tourism, Ecotourism, and Protected Areas: The State of Nature-based Tourism Around the World and Guidelines for its Development. IUCN, Cambridge, UK.

Chi Y. and Luzar E.J. 1998. An economic analysis of non-consumptive wildlife recreation expenditures. Louisiana Rural Economist 60: 8-11

Child B. 1996. The practice and principles of community-based wildlife management in Zimbabwe: the CAMPFIRE programme. Biodiversity and Conservation 5: 369-398.

Coburn B.A. 1984. Sagarmatha: managing a Himalayan World Heritage site. Parks 9: 10-13.

Davis D. and Tisdell C.A. 1998. Tourist levies and willingness to pay for a whale shark experience. Tourism Economics 5: 161-174.

De Groot R.S. 1983. Tourism and conservation in the Galapagos Islands. Biological Conservation 26: 291-300.

Durbin J.C. and Ratrimoarisaona S.N. 1996. Can tourism make a major contribution to the conservation of protected areas in Madagascar? Biodiversity and Conservation 5: 345-353.

Fennell D.A. 1999. Ecotourism: An Introduction. Routledge, London.

Goodwin H. 1996. In pursuit of ecotourism. Biodiversity and Conservation 5: 277-291.

Gossling S. 1999. Ecotourism: a means to safeguard biodiversity and ecosystem functions? Ecological Economics 29: 303-320.

Groombridge B. 1992. Global Biodiversity. Chapman \& Hall, London.

Gurung C.P. and De Coursey M. 1994. The Annapurna Conservation Area Project: a pioneering example of sustainable tourism? In: Cater E. and Lowman G. (eds) Ecotourism: A Sustainable Option? John Wiley \& Sons, Chichester, UK, pp. 177-194.

Heywood V.H. 1995. Global Biodiversity Assessment. Cambridge University Press, Cambridge, UK.

Hoyt E. 1996. Whale watching: a global overview of the industry's rapid growth and some implications and suggestions for Australia. In: Colgan K., Prasser S. and Jeffery A. (eds) Encounters with Whales, 1995 Proceedings. Australian Nature Conservation Agency, Canberra, Australia, pp. 31-36.

Hulme D. and Murphree M. 2001. African Wildlife and Livelihoods. James Currey, Oxford, UK.

Isaacs J.C. 2000. The limited potential of ecotourism to contribute to wildlife conservation. Wildlife Society Bulletin 28: 61-69.

Kallen C. 1990. Tourism as a conservation tool. Working paper, World Resources Institute, Washington, DC.

Kenchington R.A. 1989. Tourism in the Galapagos Islands: the dilemma of conservation. Environmental Conservation 16: 227-236.

King D.A. and Stewart W.P. 1996. Ecotourism and commodification: protecting people and places. Biodiversity and Conservation 5: 293-305.

Kinnaird M.F. and O'Brien T.G. 1996. Ecotourism in the Tangkoko DuaSudara Nature Reserve: opening Pandora's box? Oryx 30: 65-73.

Leader-Williams N. 2002. Animal conservation, carbon and sustainability. Philosophical Transactions of the Royal Society of London Series A 360: 1787-1806.

Liddle M.J. 1997. Recreation Ecology: The Ecological Impact of Outdoor Recreation and Ecotourism. Chapman \& Hall, London.

Loon R.M. and Polakow D. 2001. Ecotourism ventures: rags or riches? Annals of Tourism Research 28: 892-907.

Margoluis R. and Salafsky N. 1998. Measures of Success: Designing, Managing, and Monitoring Conservation and Development Projects. Islands Press, Washington, DC. 
McNeely J.A. 1994. Protected areas for the 21st century: working to provide benefits to society. Biodiversity and Conservation 3: 390-405.

McNeely J.A., Miller K.R., Reid W.V., Mittermeier R.A. and Werner T.B. 1990. Conserving the World's Biological Diversity. World Bank, Washington, DC.

Moran D. 1994. Contingent valuation and biodiversity: measuring the user surplus of Kenyan protected areas. Biodiversity and Conservation 3: 663-684.

Munn C.A. 1992. Macaw biology and ecotourism, or when a bird in the bush is worth two in the hand. In: Beissinger S.R. and Snyder N.F.R. (eds) New World Parrots in Crisis: Solutions from Conservation Biology. Smithsonian Institution Press, Washington, DC, pp. 47-72.

Myers N. 1972. National Parks in savannah Africa. Science 178: 1255-1263.

Myers N., Mittermeier R.A., Mittermeier C.G., Da Fonseca G.A.B. and Kent J. 2000. Biodiversity hotspots for conservation priorities. Nature 403: 853-858.

Nolan M.L. and Nolan S. 1998. Limits to ecotourism growth and sustainability: the Galapagos example. In: Oppermann M. (ed) Pacific Rim Tourism. CAB International, Wallingford, UK, pp. 144-155.

Perez M.R. and Byron N. 1999. A methodology to analyze divergent case studies of non-timber forest products and their development potential. Forest Science 45: 1-14.

Place S.E. 1991. Nature tourism and rural development in Tortuguero. Annals of Tourism Research 18: 186-201.

Reid D.G. 1999. Ecotourism Development in Eastern and Southern Africa. University of Guelph Press, Guelph, Canada.

Ruschmann D.V.D.M. 1992. Ecological tourism in Brazil. Tourism Management 13: 125-128.

Salafsky N. and Margoluis R. 1999. Threat reduction assessment: a practical and cost-effective approach to evaluating conservation and development projects. Conservation Biology 13: 830-841.

Salafsky N., Cauley H., Balachander G., Cordes B., Parks J., Margoluis C. et al. 2001. A systematic test of an enterprise strategy for community-based biodiversity conservation. Conservation Biology 15: 15851595.

Salewski V., Göken F., Korb J. and Schmidt S. 2000. Has the white-necked rockfowl Picathartes gymnocephala still a chance in Lamto, Ivory Coast? Bird Conservation International 10: 41-46.

Shackley M. 1995. The future of gorilla tourism in Rwanda. Journal of Sustainable Development 3 : 61-72.

Shackley M. 1996. Too much room at the inn? Annals of Tourism Research 23: 449-462.

Steele P. 1995. Ecotourism: an economic analysis. Journal of Sustainable Tourism 3: 29-44.

Stiles G.F. and Clark D.A. 1989. Conservation of tropical rain forest birds: a case study from Costa Rica. American Birds 43: 420-428.

Vickland K. 1989. New tourists want new destinations. Travel and Tourism Executive Report 9: $1-4$.

Vivanco L.A. 2001. Spectacular quetzals, ecotourism, and environmental futures in Monte Verde, Costa Rica. Ethnology 40: 79-92.

Wall G. 1997. Is ecotourism sustainable? Environmental Management 21: 483-491.

Walpole M.J., Goodwin H.J. and Ward K.G.R. 2001. Pricing policy for tourism in protected areas: lessons from Komodo National Park, Indonesia. Conservation Biology 15: 218-227.

Wearing S. and Neil J. 1999. Ecotourism: Impacts, Potentials and Possibilities. Butterworth Heinemann, Oxford, UK.

Weaver D.B. 1991. Alternatives to mass tourism in Dominica. Annals of Tourism Research 18: 414-432.

Weaver D.B. 1998. Ecotourism in the Less Developed World. CAB International, Wallingford, UK.

Wells M.P. 1992. Biodiversity conservation, affluence and poverty: mismatched costs and benefits and efforts to remedy them. Ambio 21: 237-243.

Wells M.P. 1993. Neglect of biological riches: the economics of nature tourism in Nepal. Biodiversity and Conservation 2: 445-464.

Wheeller B. 1992. Is progressive tourism appropriate? Tourism Management 13: 104-105.

Wight P. 1996. North American ecotourists: market profile and trip characteristics. Journal of Travel Research 34: 2-10. 
Wilson C. and Tisdell C. 2001. Sea turtles as a non-consumptive tourism resource especially in Australia. Tourism Management 22: 279-288.

World Commission on Environment and Development, WCED 1987. Our common future. Oxford University Press, Oxford, UK.

Zar J.H. 1999. Biostatistical Analysis. Prentice Hall, Upper Saddle River, New Jersey. 